International Journal of Design and Manufacturing

Technology (IJDMT),

ISSN 0976 - 6995(Print), ISSN 0976 - 7002(Online)

Volume 2, Issue 1, January-December (2011), pp. 47-56

(C) IAEME, http://www.iaeme.com/ijdmt.html

\title{
OPTIMIZATION OF CYLINDRICAL GRINDING PROCESS PARAMETERS FOR AISI 5120 STEEL USING TAGUCHI METHOD
}

\author{
Kirankumar Ramakantrao Jagtap \\ Assistant Professor \\ Mechanical Engineering Department \\ MGM's Jawaharlal Nehru Engineering College, \\ Aurangabad, Maharashtra, India \\ E-Mail ID: kkumar.jnec.mech@gmail.com \\ S.B.Ubale \\ Associate Professor \\ Mechanical Engineering Department \\ MGM's Jawaharlal Nehru Engineering College, \\ Aurangabad, Maharashtra, India \\ E-Mail ID: ubalesb@yahoo.co.in \\ Dr.M.S.Kadam \\ Associate Professor \\ Mechanical Engineering Department \\ MGM's Jawaharlal Nehru Engineering College, \\ Aurangabad, Maharashtra, India \\ E-Mail ID: mdaskadam@rediffmail.com
}

\begin{abstract}
The demand for closely controlling both dimensional and geometrical accuracy of engineering components made up of difficult-to-shape material is increasing continuously. The wider and newer application requirements are very demanding. To attain the closer tolerances with required surface finish, the most acceptable abrasive machining process is grinding process. Cylindrical grinding is one of the important metal cutting processes used extensively in the finishing operations. Metal removal rate and surface finish are the important output responses in the production with respect to quantity and quality respectively. The main objective of this paper is to arrive at the optimal grinding conditions that will minimize surface roughness and maximize metal removal rate when grinding AISI 5120 steel. Empirical models were developed using design of experiments by Taguchi L9 Orthogonal Array and the adequacy of the developed model is tested with ANOVA. The developed model can be used by the different manufacturing firms to select appropriate combination of machining parameters to achieve an optimal metal removal rate (MRR) and surface roughness $\left(R_{a}\right)$. The input parameters considered are: wheel speed, work speed, number of passes and depth of cut and the responses are metal removal rate (MRR) and surface roughness $\left(R_{a}\right)$. The results were further validated by conducting confirmation experiments.
\end{abstract}


KEY WORDS: Cylindrical Grinding, AISI 5120 steel, Surface Roughness, Material Removal Rate, Taguchi Analysis, ANOVA, S/N Ratio.

\section{INTRODUCTION}

Cylindrical grinding is an essential process for final machining of components requiring smooth surfaces and precise tolerances. As compared with other machining processes, grinding is costly operation that should be utilized under optimal conditions. Although widely used in industry, grinding remains perhaps the least understood of all machining processes. The major operating input parameters that influence the output responses, metal removal rate, surface roughness, surface damage, and temperature etc. are (i) Wheel Parameters: abrasives, grain size, grade, structure, binder, shape and dimension, etc. (ii) Workpiece Parameters: fracture mode, mechanical properties and chemical composition, etc. (iii) Process Parameters: work speed, depth of cut, feed rate, dressing condition, etc. (iv) Machine Parameters: static and dynamic characteristics, spindle system and table system etc. The present paper takes the following input processes parameters namely work speed, number of passes, wheel speed and depth of cut. The main objective of this paper is to arrive at the optimum grinding conditions that will minimize surface roughness and maximize metal removal rate when grinding AISI 5120 steel materials.

\section{LITERATURE REVIEW}

Janardhan et al ${ }^{[1]}$ proposed that in cylindrical grinding metal removal rate and surface finish are the important responses. The Experiments were conducted on CNC cylindrical grinding machine using EN8 material $(\mathrm{BHN}=30-35)$ and he found that the feed rate played vital role on responses surface roughness and metal removal rate than other process parameters.

Lee ${ }^{[2]}$ proposes a control-oriented model for the cylindrical grinding process in the statespace format. A series of experiments were conducted to confirm the dynamic relationships and determine the model coefficients. It is found that multiple grinding cycles in batch production can be promptly predicted and analyzed using the proposed model.

Alagumurthi et al ${ }^{[3]}$ aims at optimizing the amount of heat generation and modeling the temperature rise between wheel and work contact zone in a cylindrical grinding process so as to achieve better surface integrity in AISI 3310, AISI 6150 and AISI 52100 steel materials of different carbon compositions using $\mathrm{Al}_{2} \mathrm{O}_{3}$ grinding wheel. Finally, it was concluded that plastic deformation is desirable and it dominates only when depth of cut is low; In case of rough grinding, i.e., with moderate depth of cut, the effect of plastic deformation and brittle fracture are medium; the temperature developed at the contact zone is the main cause for the phase transformation, i.e., austenite to martensite.

Hassui et al ${ }^{[4]}$ proposed that, the wear of a grinding wheel has a direct effect on the workpiece vibration and both have effect on the workpiece quality, the objective of the work was to study the relation between the process vibration signals and the workpiece quality (mean roughness, circularity and burning). In order to reach this goal, several experiments were carried out on a plunge cylindrical grinding operation on CNC cylindrical grinder of an AISI 52100 quenched and tempered steel (58 HRc). The main conclusions were: (1) it is possible to have good workpiece quality even with a vibration level much higher than that obtained with a recently dressed wheel; 
International Journal of Design and Manufacturing Technology (IJDMT), ISSN 0976 - 6995(Print), ISSN 0976 - 7002(Online) Volume 2, Issue 1, January-December (2011), @ IAEME

(2) vibration during cutting phase and at the end of complete spark out can be used to monitor the wheel condition at least when high dressing overlap ratio is used; and (3) the decrease in the spark out time makes the vibration at the end of spark out increase a lot, but does not cause such a damage in surface roughness.

Nathan et al ${ }^{[5]}$ proposed that, in the grinding process, a proper estimate of the life of the grinding wheel is very useful. When this life expires, redressing is necessary. Hardened C60 steel (Rc 40) specimens were ground with an A463-K5-V10 wheel in a cylindrical grinding machine. The results revealed that the surface quality and in- service behaviour of a ground component is affected seriously by the occurrence of grinding burn. Hence, techniques for the prediction of the burn threshold are of great importance. Spark temperature can be considered to be a good representative of the grinding zone temperature.

Stetiu et al ${ }^{[6]}$ studied that in grinding, wear is an integral part of the process and a wear rate that is too slow can easily be more undesirable in its consequences than a rapid one. The experiments were performed on an external cylindrical grinding machine. The cylindrical test workpieces were made from $0.5 \%$ carbon steel rod of hardness $52 \mathrm{HRc}$. $\mathrm{Al}_{2} \mathrm{O}_{3}$ vitrified bonded grinding wheels of three different hardness's (Grade $\mathrm{J}, \mathrm{K} \& \mathrm{M}$ ) were used having grain size 40 with a medium structure. It was concluded that the hardness of a grinding wheel is the most important property affecting the wear phenomena.

Monici et al ${ }^{[7]}$ used an appropriate methodology of "grinding wheels and coolant" combinations to analyze the quantity of cutting fluid applied in the process and its consequences. Based on this analysis, they have investigated a new form of applying cutting fluid aimed at improving the performance of the process. The results revealed that, in every situation, the optimized application of cutting fluid significantly improved the efficiency of the process, particularly the combined use of neat oil and CBN grinding wheel.

Shih et al ${ }^{[8]}$ proposed that, increasing the grinding wheel speed reduces the average chip thickness and increase the effective hardness of the wheel, resulting in more efficient workpiece material removal rates when the workpiece material is ceramic or steel.

The grinding machine used in this study was Weldon AGN5 Cylindrical Grinding Machine. The grinding wheel used was vitreous bond CBN. He concluded that, during high speed grinding experiments of both zirconia and M2 steel, normal and tangential forces tend to lessen as the grinding wheel speed increases, but the surface finish is increases.

Brinksmeier ${ }^{[9]}$ explains that, in addition to coolant type, composition and filtration, coolant supply (nozzle position, nozzle geometry, supplied flow rate and jet characteristics) can influence process productivity, workpiece quality and tool wear considerably. For this reason, the development of coolant system design should be a first priority. SAE 52100 steel with different hardness values with various types of coolant combinations, with various coolant supply strategies, and with various grades (Aluminium oxide and $\mathrm{CBN}$ ) of grinding wheels have been used to optimize the cooling and lubrication process in grinding operation. It was concluded that coolant types, composition, nozzle design and flow rate can influence process productivity, workpiece quality and tool wear considerably.

Kruszynski et al ${ }^{[10]}$ states that, the traverse grinding process is still considered to be an art and in most cases relies to a great extent on experience of machine tool operators who have been in the profession for years. Due to the decreasing number of such operators a strong need to support them by the application of supervision 
International Journal of Design and Manufacturing Technology (IJDMT), ISSN 0976 - 6995(Print), ISSN 0976 - 7002(Online) Volume 2, Issue 1, January-December (2011), @ IAEME

systems is observed that incorporate more intelligence with similar generalization and adaptation abilities. For this reason, experimental investigations were carried out on a common cylindrical grinding machine. The material was 34CrA16C steel, hardened to 50 $\mathrm{HR}_{\mathrm{C}}$. 38A80KVBE aluminum oxide grinding wheel of $495 \mathrm{~mm}$ diameter was used. He concludes that, there is a possibility of an effective application of artificial intelligence methods to supervise and control the cylindrical traverse grinding process. Also the metal removal rate can be maximized in very few grinding passes.

Choi et al ${ }^{[11]}$ states that, coolant promotes the effects of lubrication, cooling and penetration, but it contains chlorine, sulfur and phosphorus to improve the grinding efficiency. This is harmful to the workers and it also causes environmental pollution. A dry grinding method with compressed cold air and conventional wet grinding with coolant were compared (CNC Cylindrical Grinding). The experiments were performed with a white alumina (WA) and a CBN wheel. The surface roughness and residual stress were measured to confirm the cooling effects of the compressed cold air. He concludes that, the surface roughness of the workpiece with compressed cold air is better than that with coolant and it becomes better as the air velocity increases. Hecker et al ${ }^{[12]}$ explains that, the quality of the surface generated by grinding determines many workpiece characteristics such as the minimum tolerances, the lubrication effectiveness and the component life, among others.

A series of experiments were performed on cylindrical grinding. The material used was hardened steel $52100\left(62 \mathrm{HR}_{\mathrm{c}}\right)$ with an aluminum oxide grinding wheel. He found that, the predicted surface roughness shows a good agreement with experimental data obtained from different kinematic conditions in cylindrical grinding.

Comley et al ${ }^{[13]}$ explains that, high efficiency deep grinding (HEDG) with its high material removal rate helps to improve cycle times while maintaining surface integrity, form and finish requirements. Thermal modeling is used to optimize the grinding cycle for an automotive steel and cast iron. He finally demonstrated that the concept of HEDG was valid for cylindrical plunge grinding using the selected steel and cast iron materials, and there was no abrasive grit or wheel failure as a result of the higher loads associated with the HEDG system at MRR up to $2000 \mathrm{~mm}^{3} / \mathrm{mm} / \mathrm{s}$.

Table 1: Chemical Composition of AISI 5120 steel

\begin{tabular}{|c|c|c|c|c|c|c|c|c|}
\hline $\begin{array}{l}\text { AISI Steel } \\
\text { Designation }\end{array}$ & \multicolumn{8}{|c|}{ Chemical Composition in Percentage $\%$} \\
\hline AISI 5120 & $\mathrm{C}$ & $\mathrm{Mn}$ & $\mathrm{Cr}$ & $\mathrm{Ni}$ & Mo & $\mathrm{S}$ & $\mathrm{P}$ & $\mathrm{Si}$ \\
\hline Steel & 0.161 & 0.75 & 1.10 & 0.06 & 0.24 & 0.021 & 0.016 & 0.19 \\
\hline
\end{tabular}

\section{Experimental Set-up and Design of Experiment}

In the present work, hardened AISI 5120 steel $\left(58 \mathrm{Hr}_{\mathrm{c}}\right)$ has been selected as work material. The chemical composition of AISI 5120 steel is shown in Table 1.The diameter and length of these 09 workpieces were $33 \mathrm{~mm}$ and $150 \mathrm{~mm}$ respectively. The tests were carried out on HMT K130U-300 High Precision Cylindrical Grinding Machine with vitrified $\mathrm{Al}_{2} \mathrm{O}_{3}$ grinding wheel $(300 \mathrm{~mm} \times 127 \mathrm{~mm} \mathrm{X} 40 \mathrm{~mm})$. Water miscible coolant with $5 \%$ concentration was supplied in all grinding experiments. The input parameters are depth of cut $\left(D_{c}\right)$, Work Speed $\left(N_{w}\right)$, Number of Passes $\left(N_{p}\right)$ and Grinding Wheel Speed $\left(N_{s}\right)$, and the responses considered are surface roughness $\left(\mathrm{R}_{\mathrm{a}}\right)$ and material removal rate (MRR). The surface roughness is measured using Mitutoyo Surf Test SJ201P for $0.8 \mathrm{~mm}$ of cut-off length over a length of $4 \mathrm{~mm}$ normal to the 
International Journal of Design and Manufacturing Technology (IJDMT), ISSN 0976 - 6995(Print), ISSN 0976 - 7002(Online) Volume 2, Issue 1, January-December (2011), @ IAEME

grinding. The MRR is calculated by taking the difference between weights of work materials before and after grinding and it is divided by the machining time. Process variables and their levels have been shown in Table 2, whereas the design of experiment based on Taguchi's L9 Orthogonal Array method is shown in Table 3. The obtained values of responses are then compared with predicted values of regression equations. Minitab 16.1 version statistical software is used to generate regression equations and for analysis of obtained data Taguchi Method is used.

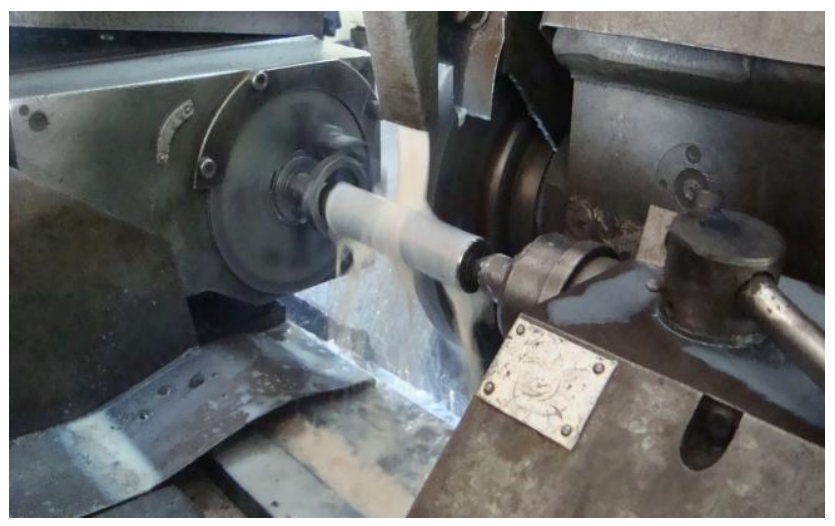

Fig.1 Experimental Set-up for cylindrical grinding of hardened AISI 5120 steel.

Table 2: Process variables and their levels for cylindrical grinding process using AISI 5120 steel

\begin{tabular}{|c|c|c|c|c|c|}
\hline Level & $\begin{array}{c}\text { Depth of } \\
\text { Cut } \\
\left(\mathrm{D}_{\mathrm{c}}\right) \mu \mathrm{m}\end{array}$ & $\begin{array}{c}\text { Work } \\
\text { Speed } \\
(\mathrm{Nw}) \mathrm{rpm}\end{array}$ & $\begin{array}{c}\text { Number } \\
\text { of passes } \\
\left(\mathrm{N}_{\mathrm{p}}\right) \text { units }\end{array}$ & $\begin{array}{c}\text { Grinding } \\
\text { Wheel } \\
\text { Speed }\left(\mathrm{N}_{\mathrm{s}}\right) \\
\mathrm{rpm}\end{array}$ & Remark \\
\hline 1 & 300 & 80 & 3 & 1910 & Low \\
\hline 2 & 400 & 224 & 6 & 2120 & Medium \\
\hline 3 & 500 & 630 & 9 & 2120 & High \\
\hline
\end{tabular}

Table 3: Design of Experiment for Grinding of hardened AISI 5120 with $\mathrm{A}_{2}{ }_{2} \mathrm{O}_{3}$ Grinding Wheel

\begin{tabular}{|c|c|c|c|c|c|c|}
\hline Run & $\begin{array}{c}\mathrm{Dc} \\
(\mu \mathrm{m})\end{array}$ & $\begin{array}{c}\mathrm{Nw} \\
(\mathrm{rpm})\end{array}$ & $\begin{array}{c}\mathrm{Np} \\
(\text { units })\end{array}$ & $\begin{array}{c}\mathrm{Ns} \\
(\mathrm{rpm})\end{array}$ & $\mathrm{Ra}(\mu \mathrm{m})$ & $\begin{array}{c}\text { MRR } \\
(\mathrm{Gms} / \mathrm{s})\end{array}$ \\
\hline 01 & 300 & 80 & 3 & 1910 & 0.45 & 0.1578 \\
\hline 02 & 300 & 224 & 6 & 2120 & 0.39 & 0.1171 \\
\hline 03 & 300 & 630 & 9 & 2120 & 0.29 & 0.1044 \\
\hline 04 & 400 & 80 & 6 & 2120 & 0.50 & 0.1308 \\
\hline 05 & 400 & 224 & 9 & 1910 & 0.40 & 0.1229 \\
\hline 06 & 400 & 630 & 3 & 2120 & 0.28 & 0.1450 \\
\hline 07 & 500 & 80 & 9 & 2120 & 0.50 & 0.1205 \\
\hline 08 & 500 & 224 & 3 & 2120 & 0.45 & 0.1568 \\
\hline 09 & 500 & 630 & 6 & 1910 & 0.25 & 0.1510 \\
\hline
\end{tabular}


International Journal of Design and Manufacturing Technology (IJDMT), ISSN 0976 - 6995(Print), ISSN 0976

- 7002(Online) Volume 2, Number 1, May - October (2011), (C IAEME

Table 4: Estimated Model Coefficients for $\mathrm{S} / \mathrm{N}$ ratios (Surface Roughness)

\begin{tabular}{|c|c|c|c|c|}
\hline Term & Coef & SE Coef & $\mathrm{T}$ & $\mathrm{P}$ \\
\hline Constant & 8.56967 & 0.2234 & 38.360 & 0.017 \\
\hline Dc $300 \mu \mathrm{m}$ & 0.18880 & 0.2979 & 0.634 & 0.640 \\
\hline Dc $400 \mu \mathrm{m}$ & -0.08795 & 0.2979 & -0.295 & 0.817 \\
\hline Nw 80rpm & -2.10772 & 0.2979 & -7.076 & 0.089 \\
\hline $\mathrm{Nw} 224 \mathrm{rpm}$ & -0.74228 & 0.2979 & -2.492 & 0.243 \\
\hline $\mathrm{Np} 3$ & -0.12392 & 0.2979 & -0.416 & 0.749 \\
\hline $\mathrm{Np} 6$ & 0.31347 & 0.2979 & 1.052 & 0.484 \\
\hline Ns1910rpm & 0.40891 & 0.2234 & 1.830 & 0.318 \\
\hline
\end{tabular}

\section{RESULTS AND DISCUSSIONS}

Table 6 and Figure 2 depict the factor effect on surface roughness. The higher the signal to noise ratio, the more favorable is the effect of the input variable on the output. The graph shows that, the optimum value levels for best surface roughness (minimum) are at a depth of cut $300 \mu \mathrm{m}$, work speed $630 \mathrm{rpm}$, number of passes 6 and grinding wheel speed of $1910 \mathrm{rpm}$. It can be seen that the most influencing parameter to surface roughness for AISI 5120 is work speed $\left(\mathrm{N}_{\mathrm{w}}\right)$ in rpm followed by grinding wheel speed, number of passes and depth of cut.

$\underline{S}=0.6319 \mathrm{R}-\mathrm{Sq}=99.0 \% \mathrm{R}-\mathrm{Sq}(\operatorname{adj})=92.3 \%$

Table 5: Analysis of Variance for $\mathrm{S} / \mathrm{N}$ ratios (Surface Roughness)

\begin{tabular}{|c|c|c|c|c|c|c|}
\hline Source & DF & Seq SS & Adj SS & Adj MS & F & P \\
\hline Dc & 2 & 0.1607 & 0.1607 & 0.0803 & 0.20 & 0.844 \\
\hline Nw & 2 & 39.3477 & 39.3477 & 19.6739 & 49.28 & 0.100 \\
\hline $\mathrm{Np}$ & 2 & 0.4486 & 0.4486 & 0.2243 & 0.56 & 0.686 \\
\hline Ns & 1 & 1.3377 & 1.3377 & 1.3377 & 3.35 & 0.318 \\
\hline Residual Error & 1 & 0.3993 & 0.3993 & 0.3993 & & \\
\hline Total & 8 & 41.6940 & & & & \\
\hline
\end{tabular}

Table 6: Response Table for Signal to Noise Ratios - Smaller is better (Surface Roughness)

\begin{tabular}{|c|c|c|c|c|}
\hline Level & $\begin{array}{c}\text { Depth of } \\
\text { Cut }(\boldsymbol{\mu m})\end{array}$ & $\begin{array}{c}\text { Work } \\
\text { Speed(rpm) }\end{array}$ & $\begin{array}{c}\text { No. of } \\
\text { Passes }\end{array}$ & $\begin{array}{c}\text { Grinding Wheel Speed } \\
(\mathbf{r p m})\end{array}$ \\
\hline 1 & $\mathbf{8 . 6 2 2} * * *$ & 6.326 & 8.309 & $\mathbf{8 . 9 7 9} * * *$ \\
\hline 2 & 8.345 & 7.691 & $\mathbf{8 . 7 4 7 * * *}$ & 8.161 \\
\hline 3 & 8.333 & $\mathbf{1 1 . 2 8 3} * * *$ & 8.244 & 0.818 \\
\hline Delta & 0.290 & 4.958 & 0.503 & 2 \\
\hline Rank & 4 & 1 & 3 & \\
\hline
\end{tabular}

*** indicates higher S/N Ratio 


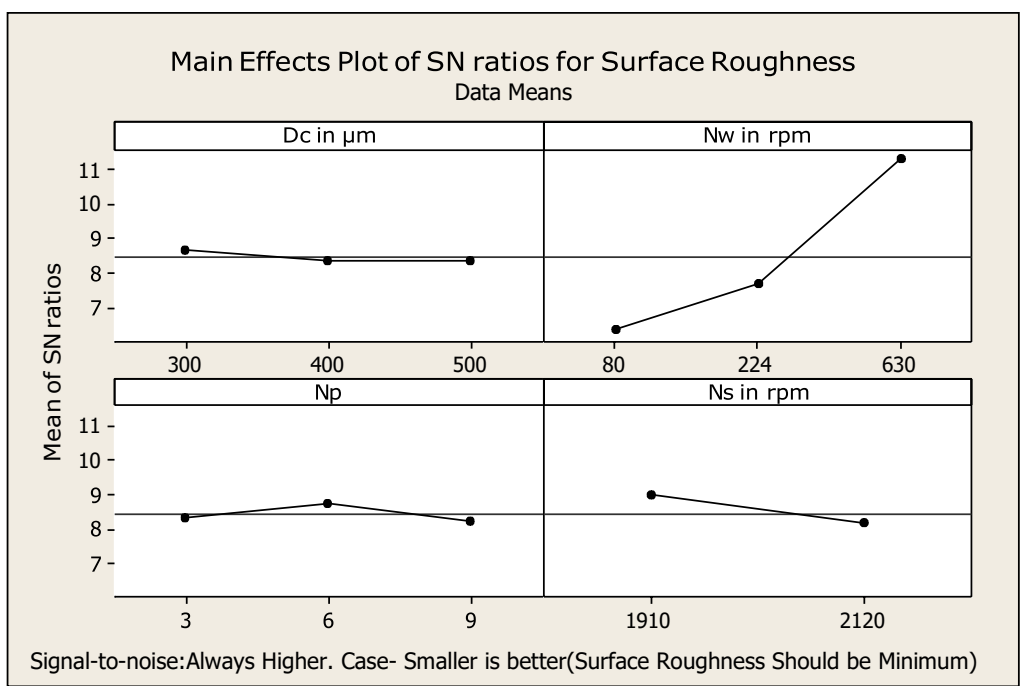

Fig 2: Main Effect Plot of S/N ratios for Surface Roughness

Table 7: Estimated Model Coefficients for $\mathrm{S} / \mathrm{N}$ ratios (MRR)

\begin{tabular}{|c|c|c|c|c|}
\hline Term & Coef & SE Coef & $\mathrm{T}$ & $\mathrm{P}$ \\
\hline Constant & -17.3737 & 0.05640 & -308.034 & 0.002 \\
\hline Dc $300 \mu \mathrm{m}$ & -0.5611 & 0.07520 & -7.461 & 0.085 \\
\hline $\mathrm{Dc} 400 \mu \mathrm{m}$ & -0.0121 & 0.07520 & -0.161 & 0.898 \\
\hline Nw 80rpm & 0.1743 & 0.07520 & 2.318 & 0.259 \\
\hline Nw 224rpm & -0.1054 & 0.07520 & -1.401 & 0.395 \\
\hline $\mathrm{Np} 3$ & 1.2345 & 0.07520 & 16.416 & 0.039 \\
\hline $\mathrm{Np} 6$ & -0.0343 & 0.07520 & -0.456 & 0.728 \\
\hline Ns1910rpm & 0.4859 & 0.05640 & 8.614 & 0.074 \\
\hline
\end{tabular}

$\underline{\mathrm{S}}=0.1595 \mathrm{R}-\mathrm{Sq}=99.8 \% \mathrm{R}-\mathrm{Sq}(\mathrm{adj})=98.4 \%$

Table 8: Analysis of Variance for $\mathrm{S} / \mathrm{N}$ ratios (Material Removal Rate)

\begin{tabular}{|c|c|c|c|c|c|c|}
\hline Source & DF & Seq SS & Adj SS & Adj MS & F & P \\
\hline Dc & 2 & 1.9305 & 1.93050 & 0.96525 & 37.93 & 0.114 \\
\hline $\mathrm{Nw}$ & 2 & 0.1387 & 0.13872 & 0.06936 & 2.73 & 0.394 \\
\hline $\mathrm{Np}$ & 2 & 8.8972 & 8.89731 & 4.44861 & 174.80 & 0.053 \\
\hline $\mathrm{Ns}$ & 1 & 1.8885 & 1.88849 & 1.88849 & 74.21 & 0.074 \\
\hline $\begin{array}{c}\text { Residual } \\
\text { Error }\end{array}$ & 1 & 0.0254 & 0.02545 & 0.02545 & & \\
\hline Total & 8 & 12.8804 & & & & \\
\hline
\end{tabular}

Table 9: Response Table for Signal to Noise Ratios - Larger is better (Material Removal Rate)

\begin{tabular}{|c|c|c|c|c|}
\hline Level & $\begin{array}{c}\text { Depth of } \\
\text { Cut }(\boldsymbol{\mu m})\end{array}$ & Work Speed(rpm) & No. of Passes & $\begin{array}{c}\text { Grinding Wheel } \\
\text { Speed (rpm) }\end{array}$ \\
\hline 1 & -18.10 & $\mathbf{- 1 7 . 3 6} * * *$ & $\mathbf{- 1 6 . 3 0 * * *}$ & $\mathbf{- 1 6 . 8 9 * * *}$ \\
\hline 2 & -17.55 & -17.64 & -17.57 & -17.86 \\
\hline 3 & $-\mathbf{1 6 . 9 6}^{* * *}$ & -17.60 & -18.74 & \\
\hline Delta & 1.13 & 0.28 & 2.43 & 0.97 \\
\hline Rank & 2 & 4 & 1 & 3 \\
\hline
\end{tabular}

*** indicates higher S/N Ratio 


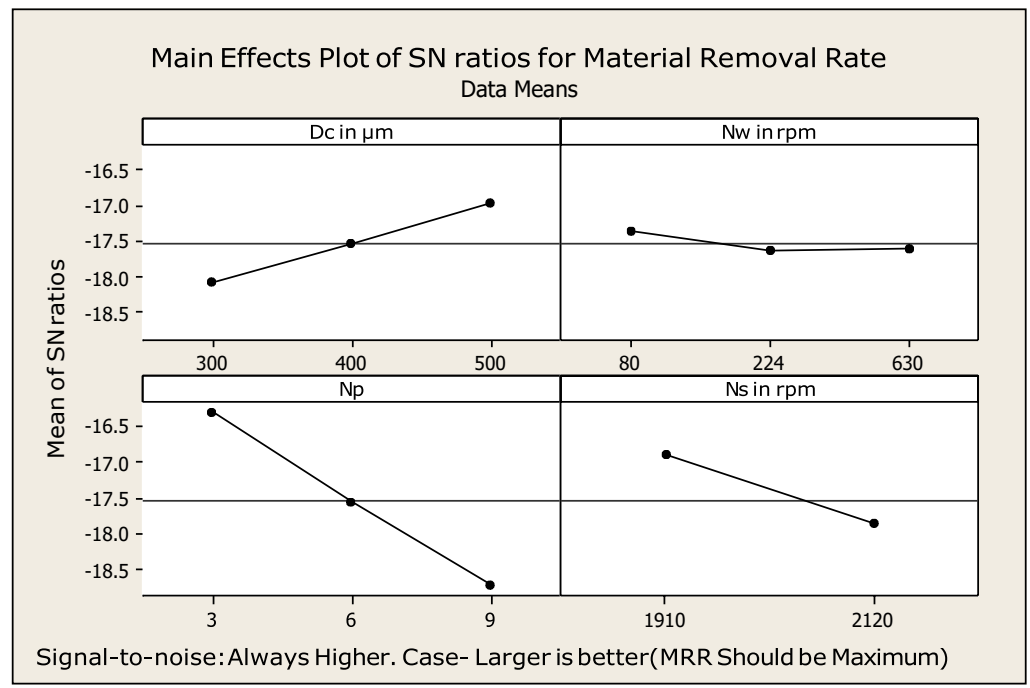

Fig 3: Main Effect Plot of S/N Ratios for Material Removal Rate

Table 9 and Figure 3 depict the factor effect on material removal rate. The higher the signal to noise ratio, the more favorable is the effect of the input variable on the output. The graph shows that, the optimum value levels for best material removal rate (maximum) are at a depth of cut $500 \mu \mathrm{m}$, work speed $80 \mathrm{rpm}$, no. of passes 3, and grinding wheel speed of $1910 \mathrm{rpm}$.

Also, for material removal rate, from Table 5 and Figure 3 it can be seen that, the most significant factor is number of passes $\left(\mathrm{N}_{\mathrm{p}}\right)$ followed by depth of cut, grinding wheel speed and work speed. For validation, the predicted values obtained by regression equations 1 and 2 for surface roughness and material removal rate respectively are compared with the experimental values. Also, the optimum set of parameters obtained from analysis is shown in Table 10.

Regression Equation for Surface Roughness for grinding of AISI 5120 steel $\mathrm{R}_{\mathrm{a}}=0.115+0.000117 \mathrm{Dc}-0.000374 \mathrm{Nw}+0.00056 \mathrm{~Np}+0.000167 \mathrm{Ns} \ldots \ldots \ldots$ (Equation 01)

Regression Equation for Material Removal Rate for grinding of AISI 5120 steel $\mathrm{MRR}=0.284+0.000082 \mathrm{Dc}-0.000003 \mathrm{Nw}-0.00621 \mathrm{~Np}-0.000070 \mathrm{Ns}$ (Equation 02)

Table 10: Optimum Set of Parameters

\begin{tabular}{|c|c|c|}
\hline \multirow{2}{*}{ Optimal Set For } & Controlled Factors & Optimum Set \\
\hline \multirow{3}{*}{ Surface Roughness $\left(\mathrm{R}_{\mathrm{a}}\right.$ in $\left.\mu \mathrm{m}\right)$} & $\mathrm{Dc}(\mu \mathrm{m})$ & 300 \\
\cline { 2 - 3 } & $\mathrm{Nw}(\mathrm{rpm})$ & 630 \\
\cline { 2 - 3 } & $\mathrm{Np}(\mathrm{units})$ & 6 \\
\cline { 2 - 3 } & $\mathrm{Ns}(\mathrm{rpm})$ & 1910 \\
\hline \multirow{3}{*}{ Metal Removal Rate $(\mathrm{Grams} / \mathrm{Sec})$} & $\mathrm{Dc}(\mu \mathrm{m})$ & 800 \\
\cline { 2 - 3 } & $\mathrm{Nw}(\mathrm{rpm})$ & 3 \\
\cline { 2 - 3 } & $\mathrm{Np}(\mathrm{units})$ & 1910 \\
\cline { 2 - 3 } & $\mathrm{Ns}(\mathrm{rpm})$ & \\
\hline
\end{tabular}

\section{Confirmation of Experiment}

Two confirmation experiments were conducted at the optimum set of the process parameters. The value of surface roughness at the optimum set of the process parameters was $0.24 \mu \mathrm{m}$ and it fall near the predicted value of $0.24 \mu \mathrm{m}$. The value of metal removal rate (MRR) at the optimum set of the process parameters was $0.1710 \mathrm{gms} / \mathrm{sec}$ and it fall near the predicted value of $0.1724 \mathrm{gms} / \mathrm{sec}$. 
International Journal of Design and Manufacturing Technology (IJDMT), ISSN 0976 - 6995(Print), ISSN 0976 - 7002(Online) Volume 2, Number 1, May - October (2011), (C IAEME

\section{CONCLUSIONS}

For Surface Roughness $\left(\mathbf{R}_{\mathbf{a}}\right)$, the work speed (Nw) was the most influencing factor for AISI 5120 work material followed by grinding wheel speed, number of passes and depth of cut. So, to achieve the minimum surface roughness of AISI 5120 steel, employ low depth of cut of 300 $\mu \mathrm{m}$, highest work speed of $630 \mathrm{rpm}$ with moderate number of passes 06 and high grinding wheel speed of $1910 \mathrm{rpm}$.

For Metal Removal Rate (MRR), for the work material AISI 5120, the most influencing factor was number of passes (Np), second being depth of cut (Dc) followed by grinding wheel speed and work speed ( $\mathrm{Nw}$ ). So, to achieve the maximum metal removal rate of AISI 5120 steel, employ highest depth of cut of $500 \mu \mathrm{m}$, lowest work speed of $80 \mathrm{rpm}$ with minimum number of passes of 03 and high grinding wheel speed of $1910 \mathrm{rpm}$.

\section{REFERENCES}

[01] M.Janardhan, A.Gopala Krishna, "Determination and optimization of cylindrical grinding process parameters using taguchi method and regression analysis", ISSN 0975- 5462, volume 3 , page 5659-5665.

[02] Cheol W. Lee, "A control-oriented model for the cylindrical grinding process",

International Journal of Advance Manufacturing Technology, (2009) 44:657-666

[03] N. Alagumurthi, K. Palaniradja \& V. Soundararajan, "Heat generation and heat transfer in cylindrical grinding process - a numerical study", International Journal of Advance Manufacturing Technology, (2007) 34:474-482

[04] A. Hassui, A.E. Diniz, "Correlating surface roughness and vibration on plunge cylindrical grinding of steel”, International Journal of Machine Tools \& Manufacture 43 (2003) 855-862

[05] R. Deiva Nathan, L. Vijayaraghavan, R. Krishnamurthy, "In-process monitoring of grinding burn in the cylindrical grinding of steel”, Journal of Materials Processing Technology 91 (1999) 37-42

[06] G.Stetiu, G.K.Lal, “Wear of Grinding Wheels”, Wear, 30 (1974) 229-236

[07] Rodrigo Daun Monicia, Eduardo Carlos Bianchia,, Rodrigo Eduardo Cataib, Paulo Roberto de Aguiar, "Analysis of the different forms of application and types of cutting fluid used in plunge cylindrical grinding using conventional and superabrasive $C B N$ grinding wheels", International Journal of Machine Tools \& Manufacture 46 (2006) 122-131

[08] A.J.Shih, M.B.Grant, T.M.Yunushonis, T.O.Morris, S.B.McSpadden, "Vitreous bond CBN wheel for high speed grinding of Zirconia and M2 Tool Steel”, Transactions of NAMRI/SME, Vol. 26, (1998)

[09] E. Brinksmeier, C. Heinzel, M. Wittmann, "Friction, Cooling and Lubrication in Grinding”, Annals of the ClRP Vol. 48/2/1999

[10] B. W. Kruszynski, P. Lajmert, “An Intelligent Supervision System for Cylindrical Traverse Grinding”, Institute of Machine Tools and Production Engineering, Poland.

[11] Hon Zong Choi, Suk Woo Lee, Hae Do Jeong, "The cooling effects of compressed cold air in cylindrical grinding with alumina and CBN wheels", Journal of Materials Processing Technology 127 (2002) 155-158

[12] Rogelio L. Hecker, Steven Y. Liang, "Predictive modeling of surface roughness in grinding”, International Journal of Machine Tools \& Manufacture 43 (2003) 755-761

[13] P. Comley, I. Walton2, T. Jin, D.J. Stephenson, "A High Material Removal Rate Grinding Process for the Production of Automotive Crankshafts", Annals of the CIRP Vol. 55/1/2006 [14] Uddeholm, in "Grinding of Tool Steel". 
International Journal of Design and Manufacturing Technology (IJDMT), ISSN 0976 - 6995(Print), ISSN 0976 - 7002(Online) Volume 2, Number 1, May - October (2011), (C) IAEME

[15] W.Graham and A.Y.C.Nee, "The Grinding of Tool Steels - A Comparison between Diamond and Cubic Boron Nitride”, International Journal of Production Research, pp. 186 - 191, June, 1974.

[16] M.J.Jackson and B.Mills in "Micro-scale wear of vitrified abrasive materials", Journal of Materials Science 39(2004), pp. 2131 - 2143.

[17] A. Hassui and A.E. Diniz, in "Correlating Surface Roughness and Vibration on Plunge Cylindrical Grinding of Steel”, International Journal of Machine Tools \& Manufacture, 43 (2003), pp. $855-862$.

[18] R. Deiva Nathan, L. Vijayaraghavan and R. Krishnamurthy, in "In-process Monitoring of Grinding Burn in the cylindrical grinding of Steel”, Journal of Materials and Processing Technology, 91 (1999), pp. 37 - 42.

[19] G. Stetiu and G.K. Lal, in "Wear of Grinding Wheels”, Wear, 30 (1974), pp. 229 - 236. [20] S.J. Pande, S.N. Halder and G.K. Lal, in "Evaluation of Grinding Wheel Performance", Wear, 58 (1980), pp. $237-248$.

[21] M.J. Jackson, C.J. Davis, M.P. Hitchiner and B. Mills, in "High-speed Grinding with CBN Grinding Wheels - Applications and Future Technology”, Journal of Materials and Processing Technology 110 (2001), pp. $78-88$.

[22] D.J.Stephenson, D.Veselovac, S.Manley, and J.Corbett, in "Ultra-Precision Grinding of Hard Steels", Journal of the International Societies for Precision Engineering and Nanotechnology 25 (2001), pp. $336-345$.

[23] T.C. Buttery, A. Statham, J.B. Percival and M.S. Hamed, in "Some Effects of Dressing on Grinding Performance”, Wear, 55 (1979), pp. 195 - 219.

[24] Taghi Tawakoli and Bahman Azarhoushang, in "Influence of Ultrasonic Vibrations on Dry Grinding of Soft Steel”, International Journal of Machine Tools \& Manufacture, 48 (2008), pp. 1585 - 1591.

[25] Rodrigo Daun Monici, Eduardo Carlos Bianchi, Rodrigo Eduardo Catai, and Paulo Roberto de Aguiar, in "Analysis of the Different Forms of Application and Types used in Plunge Cylindrical Grinding using Conventional and Superabrasive CBN Grinding Wheels", International Journal of Machine Tools \& Manufacture, 46 (2006), pp. 122 - 131. 